〔ミニレビュー〕

\title{
黒毛和種の全国的な遺伝的能力評価 （肉用牛広域後代検定）
}

\author{
井上慶一 \\ (独) 家畜改良センター 改良部 情報分析課
}

\section{A Challenge to a national genetic evaluation for Japanese Black Cattle in Japan (An inter-prefecture progeny testing scheme for beef cattle)}

\section{Keiichi INOUE}

\author{
National Livestock Breeding Center
}

\section{1. はじめに}

国が肉用牛の改良を目的に行う補助事業として、平 成 11 年度から肉用牛広域後代検定推進事業 (現: 肉用 牛広域後代検定) が実施された。この事業は、都道府 県単位で行われてきた種雄牛造成について、改良の基 盤となる育種資源の多様化と選抜圧の強化を図り、よ り高能力な種雄牛の造成が可能となるよう、優良な育 種資源の広域的な利用と全国規模での能力評価体制を 確立し、県域を越えた高能力種雄牛の造成・利用を促 進するものである。

ここでは、肉用牛改良の現状と併せて肉用牛広域後 代検定の概要を簡単に紹介し、事業における広域的な 遺伝的能力評価について説明する。

\section{2. 肉用牛の改良をめぐる情勢}

（1）雌牛飼養頭数

肉用牛子取り用雌牛頭数の年次別推移を図 1 に示し た（農林水産省大臣官房統計部 2004）。飼養頭数全体 では、平成 5 年をピークに減少してきたが、平成 13 年を境に徐々に増加傾向にある。しかし、飼養頭数の 顕著な増加が見られるのは、北海道と沖縄だけであり、 その他の地域では、横這いないしやや減少傾向である。 また、主要な種雄牛の生産地域である中国地方での減 少が著しく、この 15 年間程度で約半数にまで減少し ている。

（2）検定状況

検定方法別種雄牛頭数の年度別推移を図 2 に示した

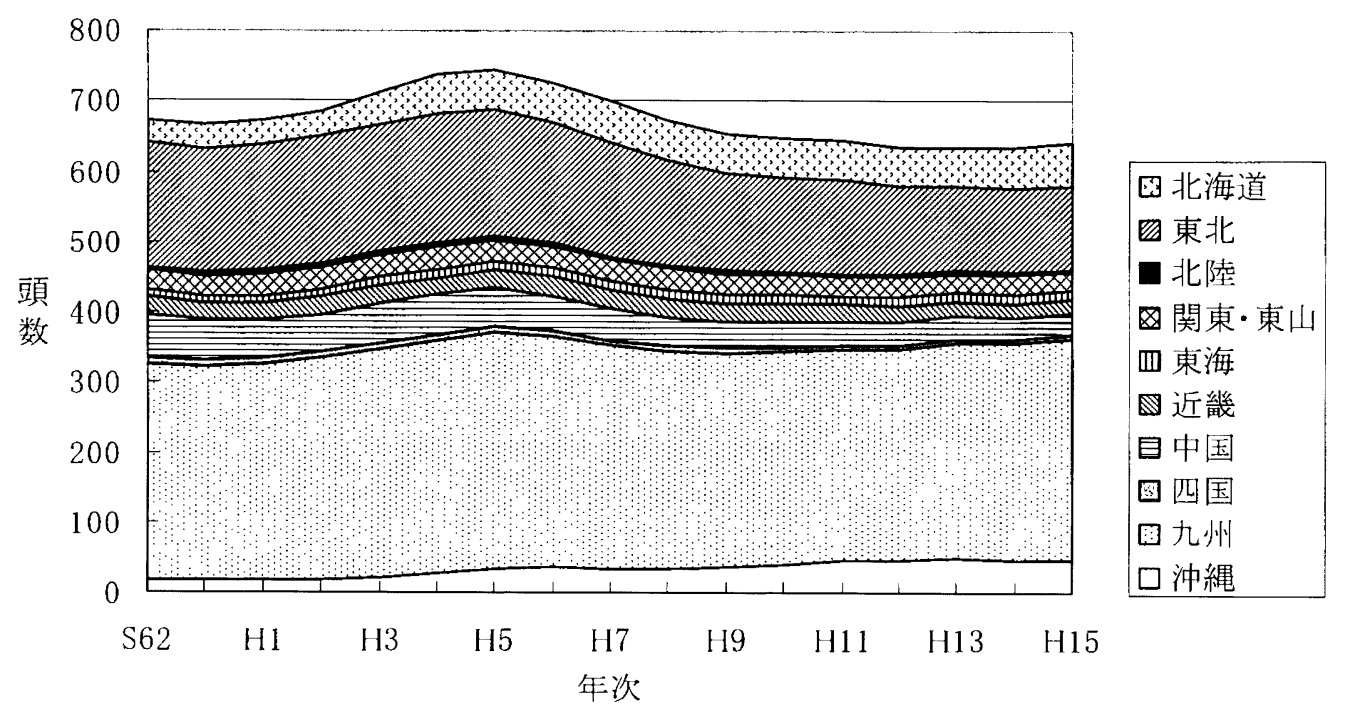

図 1. 肉用牛子取り用雌牛頭数の推移 


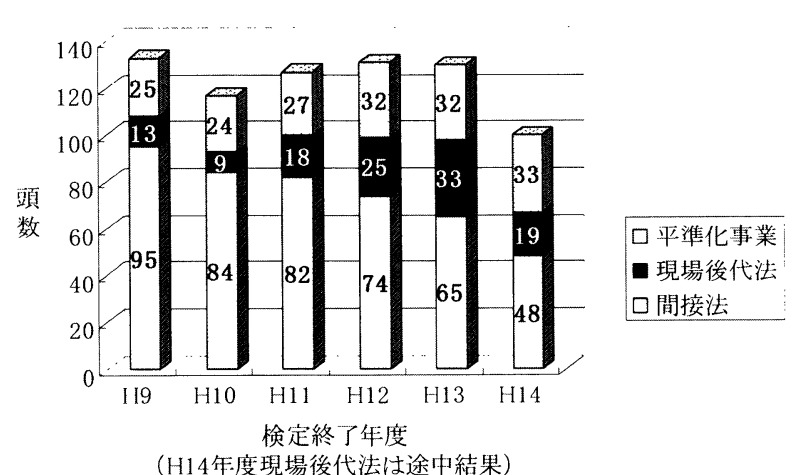

（H14年度現場後代法は途中結果）

図 2. 検定方法別頭数の推移

（社団法人全国和牛登録協会 1999、2000a、2001、2002、 2003）。検定終了年度で集計しているため、平成 14 年 度の現場後代検定については途中結果である。また、 図中の「平準化事業」とは、(社) 家畜改良事業団で実 施されている、肉用牛平準化促進事業に係る間接検定 のことである。検定頭数については、ここ 5 年程度は 大きな変化は見られず約 130 頭程度であるが、間接法 での検定頭数が減少し、代わりに現場後代検定法での 検定頭数が増加している。

この変化の大きな原因と考えられるのは、調査牛を 生産するための調整交配用雌牛の確保が困難であるこ と、一般肥育牛の成績との比較が困難であること、検
定コストの増大などが挙げられる。間接法では検定の 開始が同時期であるため、調査牛として去勢子牛を 8 頭以上ほぼ同時期に揃える必要がある(表 1 : 社団法 人全国和牛登録協会 2000b)。前述したように、育種県 での雌牛頭数が減少してきている中で、調整交配用の 雌牛を確保できないことが問題となっている。また、 検定終了月齢が 20 から 21 力月齢と、極端な若齢肥育 であることから、一般に肥育された牛の成績との比較 が難しく、検定を同一検定牛のセット毎に同時に開始 するため、育種価の算出も困難である。更に、間接法 では検定に一定の基準を満たした特別な検定施設が必 要であることから、検定施設の建設や維持·管理に費 用がかかり、また、調査牛が極端な若齢肥育牛である ことから、市場価格も通常の肥育牛より安くなってし まい、採算がとれない問題がある。

一方、現場後代検定法では、調查牛を 15 頭以上確 保する必要があるが、(社) 全国和牛登録協会での育種 価評価に打ける条件を満たしていれば、雌牛を含めて も差し支えなく、不特定数で随時検定を開始してよい (ただし、概ね 1 年以内) ことから、調整交配用の雌牛 を確保しやすい条件になっている。また、肥育終了月 齢においても、一般の肥育に近い月齢となっており、 検定施設についても、一般の肥育場 (農家)を複数利用 することができるようになっている。ただし、現場後 代検定では、間接法と比べて規定が緩和されているた め、正確な検定を行うためには、予めある程度計画さ

表 1. 後代検定方法の比較

\begin{tabular}{|c|c|c|c|}
\hline 区分 & 間接法 & 現場後代検定法 & $\begin{array}{c}\text { （参考）平準化促進事業 } \\
\text { における検定 }\end{array}$ \\
\hline 根拠 & 和牛登録協会規程 & 和牛登録協会規程 & $\begin{array}{c}\text { 家畜改良事業団 } \\
\text { 実施要領 }\end{array}$ \\
\hline 調査牛の条件 & 去勢子牛 & 雌牛を含めてもよい & 間接法と同じ \\
\hline 1 セットの頭数 & 8 頭以上 & 15 頭以上 & 15 頭程度 \\
\hline 調查牛の配置 & $\begin{array}{c}\text { 同一検定牛の息牛のみ } \\
1 \text { セット } 1 \text { カ所の施設 }\end{array}$ & $\begin{array}{c}\text { 他の種雄牛の産子との } \\
\text { 同時期肥育が望ましい } \\
\text { 複数の場所に配置 }\end{array}$ & $\begin{array}{c}\text { 複数の検定牛の息牛 } \\
2 \text { 力所に分散して配置 }\end{array}$ \\
\hline 開始時の条件 & $\begin{array}{c}\text { 同一検定牛のセット毎 } \\
\text { に同時に開始 }\end{array}$ & 不特定数で随時開始 & $\begin{array}{c}\text { 複数検定牛の息牛での } \\
\text { 構成群毎に随時開始 }\end{array}$ \\
\hline 終了時の月齢 & 概ね 20～21 力月齢 & $\begin{array}{c}\text { 去勢 } 29 \text { 力月齢未満 } \\
\text { 雌 } 32 \text { 力月齢未満 }\end{array}$ & 間接法と同じ \\
\hline 給与飼料 & 検定飼料 & 規定なし & 間接法と同じ \\
\hline 給与方法 & 自由摂取 & 規定なし & 間接法と同じ \\
\hline
\end{tabular}


れた調査牛の配置、検定が必要となってくる。

\section{3. 広域後代検定}

\section{(1) 事業の考え方}

\section{(1) 種雄牛造成上の課題}

県単位での種雄牛造成は、基本的に県内の遺伝資源 を利用していることから、上述したように県内の改良 用雌牛頭数が減少してきている中で、種雄牛造成用の 雌牛側の遺伝資源についても限られてきている状況に ある。また、造成された候補種雄牛についても、選抜 が県域という小さな単位での選抜であることから選抜 圧が低くなり、改良速度の停滞を招いていると考えら れる。

選抜された種雄牛の利用についても、自県産の種雄 牛を自県だけで利用する状況が多い現状では、生産者 側からは利用可能な種雄牛が限られることになり、供 用期間が長期化し、改良速度の停滞につながると考え られる。また、限られた種雄牛を多用することによる、 近交度の上昇、遺伝性疾患を持つものがいた場合には、 それら遺伝性疾患の顕在化が懸念される。もし、優秀 な種雄牛が作出された場合にも、県外への供用を制限 することにより、これら優秀な遺伝資源の波及効果が 小さく、国全体のベースアップにはつながらない状況 にある。

また、県を超えた種雄牛の能力の比較ができないこ とから、全国水準での能力が不明暸なため、低能力牛 の温存につながる可能性も指摘されていた。

\section{(2) 広域化のメリット}

これらの問題点に対比させて考えた場合、検定·評 価の広域化を行った場合の利点として、

-より多くの種雄牛から共同に利用可能な種雄牛 (共 同利用種雄牛) を選抜するため、能力の高い種雄牛 が選抜できる

・毎年新しい共同利用種雄牛が出てくるため、利用で きる種雄牛に幅ができ、特定の種雄牛への利用の集 中が回避できる

・種雄牛の能力を共通の土俵で比較するため、改良の レベルを把握できる

等が挙げられる。

\section{(3) 事業の開始}

以上の経緯を踏まえ、広域後代検定は都道府県の枠 を超えた後代検定・能力評価の実施による改良効率の 向上および育種資源の確保と有効利用を通じた、全国
ベースでの能力の向上を目的として開始された。

また、全国的に種雄牛が供用されることから、遺伝 的多様性の確保にも配慮した種雄牛の選抜・利用が実 施されている。

\section{（2）事業の具体的内容}

\section{(1) 検定方法}

検定方法としては、ステーション検定 (間接法) とフ イールド検定 (現場後代検定法㧍よび一般肥育を含む) の両方を採用しており、基本的には(社) 全国和牛登録 協会の検定方法に従っている（社団法人全国和牛登録 協会 2000b)。しかし、間接法から現場後代検定法へ移 行している検定実施県が増加していることや、評価值 の一本化が望まれていることから、フィールド検定一 本化への移行を進めているところである。この移行過 程措置として、フィールドにおける一般肥育牛のデー 夕を用いた広域後代検定への参加も認めている。

\section{(2) 広域後代検定参加県}

現在、国の事業で黒毛和種の検定事業を実施してい るのは 23 道県あるが、そのうち広域後代検定に参加 しているのは 20 道県である。

ステーション検定では、山形県、岐阜県、佐賀県、 長崎県、熊本県の 5 県が、フィールド検定では、北海 道、青森県、岩手県、宮城県、秋田県、福島県、茨城 県、長野県、鳥取県、島根県、岡山県、広島県、山口 県、大分県、沖縄県の 15 道県が参加している。

\section{(3) 基準種雄牛}

広域で遺伝的能力評価を行う際には、牛群間の遺伝 的連結度が高くなければ正確な評価が行えない (Wood ら 1991；Kennedy と Trus 1993）。血縁情報を通じてあ る程度の連結性を持っていると思われるものの、それ だけでは十分であるとは考えられない。このため、能 力評価を行う際に県間にブリッジをかけ、連結性をよ り高めるために基準種雄牛 2 頭の産子を各県に配置 し、 2 年毎に 1 頭を更新している。

ステーション検定では、県の検定牛と同じ検定牛房 に基準種雄牛の産子を配置する、「ステーション混飼 型」と、県の検定牛とは別の検定牛房に基準種雄牛の 産子を配置 (ただし、検定時期等は揃える)する、「ス テーション追加型」のどちらかを実施している。

フィールド検定では、県の検定調査牛が肥育されて いる検定場 (農家)に、基準種雄牛の調查牛も同時に配 置して肥育することとしている。 


\section{(4) 事業の流れ}

広域後代検定に抢ける事業の流れを簡単に図 3 市よ び4に示した。検定から選抜までの流れとしては、広 域後代検定参加道県において検定を実施し、これら検 定成績を基に家畜改良センターで遺伝的能力評価を行 い、最終的にこれらの検定成績・能力評価值等を基に 改良専門委員会と中央協議会で共同利用種雄牛の選定 を行うこととなっている(図 3)。共同利用種雄牛の選 定要件については、検定成績および能力評価值に対す る基準の他に、希少系統の種雄牛の遺伝子保有確率も 要件に入っており、遺伝的多様性の確保にも配慮した 選定要件となっている。これらの要件を満たしている 種雄牛の中で、広域後代検定実施道県から精液の利用 希望がある種雄牛抢よび改良専門委員会が特に必要と 認める種雄牛が共同利用種雄牛に選定される。

このように選定された共同利用種雄牛の精液は、全 都道府県から利用希望を取り、家畜改良センターが精 液の利用調整を、家畜改良事業団が精液の取り扱い空

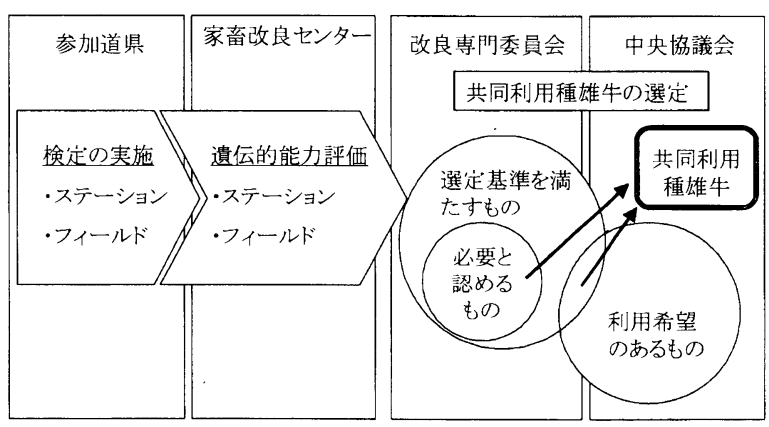

図 3. 広域後代検定事業の流れ（検定から選抜まで）

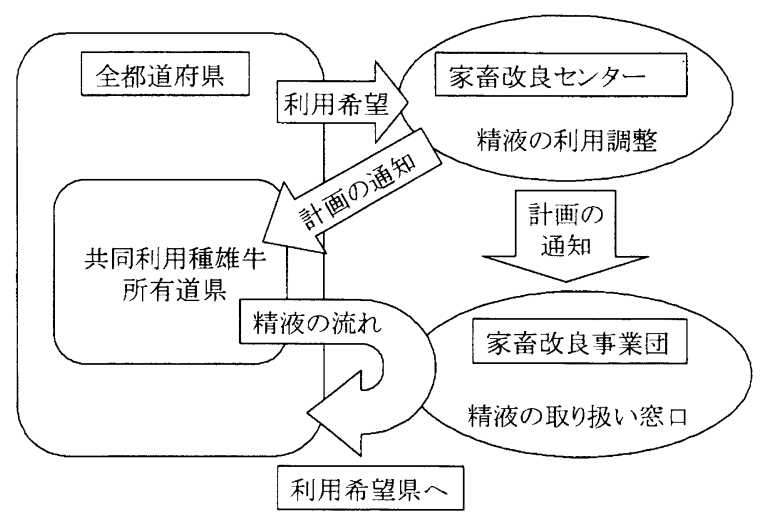

図 4. 広域後代検定事業の流れ（選抜牛の精液利用）
口となり、共同利用種雄牛所有道県から利用希望のあ った都道府県へ精液の配布を行っている(図 4)。

\section{(5) 共同利用種雄牛}

現在までに選定された共同利用種雄牛は、平成 14 年度評価分からは 7 頭 (ステーション 4 頭、フィール ド 3 頭)、平成 15 年度第 1 期評価分からは 9 頭 (ステ ーション 3 頭、フィールド 6 頭)、平成 15 年度第 2 期 評価分からは 5 頭 (フィールド 5 頭)であり、事業開始 から 21 頭が全国的に共同で利用できる種雄牛として 選定され利用されている (平成 15 年度第 2 期評価終了 現在)。

（3）遺伝的能力評価について

(1) ステーション検定とフィールド検定成績の同時評価 方法の模索

間接検定 (ステーション検定) とフィールドから得ら れた成績の関連性を調査するために、ある県における 実際の間接検定成績とフィールドでの成績を用い、そ れぞれのデータを別形質として扱って、多形質 REML 法で遺伝率および遺伝相関を推定した。

データセットとしては、ステーションとフィールド の両方のデー夕を持つ種雄牛のみのデー夕 (A1：種雄 牛 38 頭、調査牛 1,426 頭) を抽出したが、実際の広域 後代検定ではステーション検定での成績あるいはフィ ールド検定での成績しか持たない種雄牛が多く混在す るデー夕を評価することとなるため、A1 のデータセ ットから、調查牛頭数の少ない種雄牛 10 頭のフィー ルドデー夕を、調查牛頭数の多い種雄牛 10 頭のステ ーションデー夕をそれぞれ除外したデー夕 (A2：種雄 牛 38 頭、調査牛 1,169 頭) の 2 つで分析を行った。

遺伝的パラメータの推定には VCE (Groeneveld 1998) を用い、ステーションのデー夕は、と畜年月 (母数)、 個体 (変量)、肥育終了時日齢の一次回帰を入れたモデ ルで、フィールドのデー夕はこのモデルに、性、肥育 農家、市場 (いずれも母数)を加えたモデルで推定を行 った。

推定された遺伝的パラメー夕を表 2 に示した。デー タセットA1では、向井 (1994) の報告と同様に、どの 形質においてもステーションでの遺伝率はフィールド での遺伝率よりも高く推定された。また、ステーショ ン検定成績とフィールドから得られた成績との遺伝相 関は、枝肉重量で制限值になり、ロース芯面積でやや 低めに推定された他は高い值が推定された。しかし、 より広域後代検定の現実の状況に近いと思われるデー 
表2. ステーション、フィールドデータを多形質モデルで同時に推定した遺伝的パラメータ

\begin{tabular}{|c|c|c|c|c|c|c|c|c|}
\hline データセット & $\mathrm{n}$ & & DG & 枝肉重量 & ロース芯面積 & バラの厚さ & 皮下脂肪厚 & BMS \\
\hline \multirow[t]{4}{*}{$\mathrm{A} 1$} & 1,426 & & & & & & & \\
\hline & & $h^{2}-S$ & 0.650 & 0.719 & 0.312 & 0.458 & 0.598 & 0.653 \\
\hline & & $h^{2}-F$ & 0.371 & 0.316 & 0.394 & 0.298 & 0.327 & 0.524 \\
\hline & & $\mathrm{r}_{\mathrm{G}}$ & 0.903 & 1.000 & 0.572 & 0.891 & 0.911 & 0.961 \\
\hline \multirow[t]{4}{*}{ A2 } & 1,169 & & & & & & & \\
\hline & & $h^{2}-S$ & 0.749 & 0.740 & 0.176 & 0.035 & 0.914 & 0.539 \\
\hline & & $h^{2}-F$ & 0.465 & 0.324 & 0.105 & 0.322 & 0.331 & 0.505 \\
\hline & & $\mathrm{r}_{\mathrm{G}}$ & 1.000 & 1.000 & 0.256 & -1.000 & 1.000 & 0.864 \\
\hline
\end{tabular}

$\mathrm{h}^{2}$-S：ステーションデータから推定された遺伝率

$\mathrm{h}^{2}-\mathrm{F}$ ：フィールドデータから推定された遺伝率

$\mathrm{r}_{\mathrm{G}}$ : 遺伝相関

表 3. 種雄牛頭数および調查牛頭数の推移 (ステーション)

\begin{tabular}{|c|c|c|c|c|}
\hline \multirow{2}{*}{ 評価時期 } & \multicolumn{2}{|c|}{ 種雄牛数 } & \multicolumn{2}{|c|}{ 調査牛数 } \\
\hline & 紧有 & 総数 & 県有 & 総数 \\
\hline H14 & 23 & 49 & 145 & 576 \\
\hline H15-1 & 39 & 98 & 242 & 1,117 \\
\hline H15-2 & 43 & 103 & 274 & 1,157 \\
\hline
\end{tabular}

タセットA2では、ロース芯面積で遺伝相関が非常に 低くなり、バラの厚さではステーション検定の遺伝率 が非常に低くなり、遺伝相関も正の強い相関から負の 制限值へと逆転してしまった。また、データセット A1 では正常に遺伝相関が推定されたと思われた DG と皮下脂肪厚でも遺伝相関が制限值に達してしまっ た。これらのことから、デー夕数が少ないことを考慮 しても、片方の検定にしかデータが存在しないアンバ ランスなデータでは、両検定から得られたデータを用 いて同時に遺伝的パラメー夕を推定すると、推定值の 信頼性が低くなることが示唆された。

以上の結果と、ステーション検定が特異な検定方法 であること、また、脂肪交雑の評価がフィールドにお ける格付協会による評価とずれが生じている可能性が あることからも、ステーション検定とフィールド検定 の結果を同時に評価することは困難と考えられ、検定 方法毎に評価することとなった。

\section{(2) ステーション検定}

a）血縁情報

評価に用いた血縁情報については、遺伝ベースを揃 えたほうがよいと考え、1960年生まれ以降の血縁情報 を用いることとし、その範囲で調査牛より可能な限り 遡り構築した。識別できない個体についての遺伝グル ープ化は行わなかった。また、近交の影響も考えられ ることから、これらの血縁情報から、Meuwissen と Luo (1992) のアルゴリズムを用いたプログラム CoeF （佐藤 2000）で近交係数を算出し、Quaas（1976）の方 法により血縁係数行列の逆行列を構築する際に利用 した。

b）評価モデルの選定

評価に用いたデー夕数の評価回次に伴う推移を表 3 に示した。ステーション検定の評価には、県の検定牛 だけでなく、（社）家畜改良事業団の平準化事業におけ る検定牛のデー夕も利用しているため、総調査牛頭数 
が県調查牛頭数の 5 倍程度で推移しているが、平成 14 年度当初は 600 頭弱のデー夕数であった。

平成 14 年度時点での検定場毎の検定開始月および 開始季節別頭数を表 4 に示したが、特定月に特定の検 定場が検定を開始している傾向が顕著であったことが わかる。このため、開始月をより大きな括りの季節と してグルーピングした。この際、季節の概念は気温や 湿度のような外部環境を基準とした。

以上のように、データの分布を勘案しながら、評価 に用いるモデルの選定を行った。モデルに取り入れる 母数効果の候補は、検定場、検定開始月および検定開 始季節とし、デー夕数が少ないことから、各母数効果 は独立に扱うこととした。

広域的に能力評価を行う場合には、群間の遺伝的連 結度が問題となり、連結度が低ければ評価の精度も低 下することから(Wood ら 1991; Kennedy と Trus 1993)、 評価モデルの選定には、個体の育種価間の差の予測誤 差分散 (PEV) を算出し、モデルを選定する際の指標と した。

各効果を組み合わせた 4 つのモデルにより、混合モ デル方程式を作成し、その係数行列の一般逆行列を
FSPAK（Perez-Enciso ら 1994）を用いて計算し、下式に より当該個体間の差のPEV を計算した。

$$
\operatorname{Var}(\hat{a} i-\hat{a} j)=\left(C_{11(i i)}+C_{11(j j)}-2 C_{11(i j)}\right) \sigma_{\mathrm{e}}^{2}
$$

ここで、 $C_{11(i i)}$ と $C_{11(j j)}$ は、一般逆行列中の個体 $\mathrm{i}$ j了 よび $\mathrm{j}$ に相当する対角要素であり、 $C_{11(i j)}$ は、個体 $\mathrm{ij}$ 間に相当する非対角要素である。便宜上、種雄牛間の 差の PEV の平均值を指標とし、形質はBMS を取り上 げた。

平成 14 年度当初のデー夕 (種雄牛 49 頭) で行った分 析結果を表 5 に示した。

差の PEV が小さいほど、群間の遺伝的連結度が高 いこととなるが、モデルに取り入れる効果の数や効果 の水準数が少ないほど差の PEV は小さくなる。この ことを踏まえた上で分析結果から、開始季節を効果に 取り入れたモデル（2）の方が、開始月を取り入れたモ デル (1)よりも差の PEVが小さく、デー夕の連結性が 高いこと、また、これらの効果を入れていないモデル (3) とそれ程大きく差がないことから、モデル (2)で 評価を行うこととした。

表 4. 各検定場での開始月および開始季節別頭数 (ステーション)

\begin{tabular}{|c|c|c|c|c|c|c|c|c|c|c|}
\hline 開始月 & 山形 & 長野 & 鳥取 & 佐賀 & 長崎 & 熊本 & 沖縄 & LIAJ 北 & LIAJ 広 & 小計 \\
\hline 1 月 & 10 & 6 & & & & & & & & 16 \\
\hline 2月 & & & 9 & & & & & & & 9 \\
\hline 3 月 & & & & & 10 & & & & & 10 \\
\hline 4月 & & & & & & & 8 & 54 & 48 & 110 \\
\hline 5 月 & 10 & & & & 19 & & & 76 & 77 & 182 \\
\hline 6 月 & & & & & & & & 84 & 80 & 164 \\
\hline 7月 & & & & & 10 & & & & & 10 \\
\hline 8 月 & & & & & & 8 & & & & 8 \\
\hline 10 月 & & & 9 & 20 & & & 10 & & & 39 \\
\hline 11 月 & & & & & & & 9 & & & 9 \\
\hline 12 月 & & & 10 & & & 9 & & & & 19 \\
\hline 開始季節 & 山形 & 長野 & 鳥取 & 佐賀 & 長崎 & 熊本 & 沖縄 & LIAJ 北 & LIAJ 広 & 小計 \\
\hline 春 $(3 \sim 5$ 月 $)$ & 10 & & & & 29 & & 8 & 130 & 125 & 302 \\
\hline 夏 (6〜8月 $)$ & & & & & 10 & 8 & & 84 & 80 & 182 \\
\hline 秋 $(9 \sim 11$ 月 $)$ & & & 9 & 20 & & & 19 & & & 48 \\
\hline 冬（12～2月） & 10 & 6 & 19 & & & 9 & & & & 44 \\
\hline 小計 & 20 & 6 & 28 & 20 & 39 & 17 & 27 & 214 & 205 & 576 \\
\hline
\end{tabular}

LIAJ 北：家畜改良事業団北海道産肉能力検定場

LIAJ 広：家畜改良事業団広島産肉能力検定場 
表 5. 各モデルでの個体抢よび差のPEV（ステーション）

\begin{tabular}{|c|c|c|c|c|c|c|}
\hline \multirow{2}{*}{ モデル No. } & \multirow{2}{*}{\multicolumn{2}{|c|}{ 効果 }} & \multicolumn{2}{|c|}{ 個体の PEV } & \multicolumn{2}{|c|}{ 差の PEV } \\
\hline & & & 平均 & 標準偏差 & 平均 & 標準偏差 \\
\hline 1 & \multicolumn{2}{|c|}{ A, F1, F2-1, RG1 } & 1.209 & 0.660 & 2.151 & 0.960 \\
\hline 2 & \multicolumn{2}{|c|}{ A, F1, F2-2, RG1 } & 1.061 & 0.435 & 1.859 & 0.643 \\
\hline 3 & A, F1, & RG1 & 1.018 & 0.381 & 1.772 & 0.565 \\
\hline 4 & $\mathrm{~A}$, & RG1 & 0.842 & 0.130 & 1.414 & 0.186 \\
\hline
\end{tabular}

\begin{tabular}{llr} 
参考 & & \\
\hline 効果番号 & \multicolumn{1}{c}{ 効果名 } & 水準数 \\
\hline F1 & 検定場 & 9 \\
F2-1 & 開始月 & 11 \\
F2-2 & 開始季節 & 4 \\
RG1 & 開始日齢の一次回帰 & 1 \\
A & 個体 & 3,958 \\
\hline
\end{tabular}

表 6. 観測值の平均士標準偏差、最大值および最小値 (ステーション)

\begin{tabular}{lcrcc}
\hline 形質名 & 頭数 & 平均 \pm 標準偏差 & 最大值 & 最小值 \\
\hline DG $(\mathrm{kg} /$ day) & 1,157 & $0.91 \pm 0.12$ & 1.34 & 0.62 \\
BMS (No.) & & $8.21 \pm 1.90$ & 12 & 3 \\
ロース芯面積 $\left(\mathrm{cm}^{2}\right)$ & & $47.27 \pm 5.90$ & 65 & 24 \\
皮下脂肪厚 $(\mathrm{cm})$ & $2.01 \pm 0.55$ & 4.3 & 0.7 \\
枝肉重量 $(\mathrm{kg})$ & $347.89 \pm 37.29$ & 491 & 244 \\
バラの厚さ $(\mathrm{cm})$ & $6.29 \pm 0.73$ & 9.3 & 4.0 \\
歩留基準值 & $73.61 \pm 1.05$ & 76.9 & 69.1 \\
\hline
\end{tabular}

表 7. 評価に用いた効果の水準数 (ステーション)

\begin{tabular}{lc}
\hline \multicolumn{1}{c}{ 効果 } & 水準数 \\
\hline 検定場 & 10 \\
開始季節 & 4 \\
開始時日齢の一次回帰 & 1 \\
個体 (うち調查牛数) & $7,123(1,157)$ \\
\hline
\end{tabular}

表 8. 遺伝的パラメータ (ステーション)

\begin{tabular}{lcrr}
\hline 形質名 & 遺伝率 & $\begin{array}{c}\text { 遺伝分散 } \\
\left(\sigma \mathrm{a}^{2}\right)\end{array}$ & $\begin{array}{r}\text { 表型分散 } \\
\left(\sigma \mathrm{a}^{2}+\sigma \mathrm{e}^{2}\right)\end{array}$ \\
\hline $\mathrm{DG}(\mathrm{kg} / \mathrm{day})$ & 0.53 & 0.0065 & 0.0122 \\
$\mathrm{BMS}(\mathrm{No})$. & 0.75 & 2.52 & 3.37 \\
ロース芯面皘 $\left(\mathrm{cm}^{2}\right)$ & 0.64 & 20.75 & 32.42 \\
皮下脂肪厚 $(\mathrm{cm})$ & 0.34 & 0.10 & 0.29 \\
枝肉重量 $(\mathrm{kg})$ & 0.79 & $1,006.89$ & $1,271.54$ \\
バラの厚さ $(\mathrm{cm})$ & 0.64 & 0.31 & 0.49 \\
歩留基準值 & 0.50 & 0.46 & 0.93 \\
\hline
\end{tabular}


モデル式の詳細を以下に示した。現在でもこのモデ ル式で評価を行っている。

$$
\begin{aligned}
& y_{i j k}=P_{i}+S S_{j}+u_{i j k}+a l\left(t_{i j k}-T\right)+e_{i j k} \\
& \text { ここで } \quad y_{i j k}: \text { 形質の観測值 } \\
& P_{i}: \text { 検定場 (母数効果) } \\
& S S_{j}: \text { 開始季節 (母数効果) } \\
& u_{i j k}: \text { 個体の育種価 (変量効果) } \\
& t_{i j k}: \text { 検定開始日齢 } \\
& T: \text { 検定開始日齢の算術平均 } \\
& a l: \text { 検定開始日齢に対する一次回帰 } \\
& e_{i j k}: \text { 残差 }
\end{aligned}
$$

c）平成 15 年度第 2 期評他現在の状況

平成 15 年度第 2 期評価に求ける観測值の基本統計 量を表 6 に、評価に用いた各効果の水準数を表 7 に、 推定された遺伝的パラメー夕を表 8 に示した。

遺伝的パラメータの推定には MTC (Misztal ら 1992、 1993）を用いた。各個体の育種価については、MTCで 求めた遺伝抒よび残差の分散推定值を用いて JAA (Misztal と Gianola 1987) を用いて推定している。
(社) 家畜改良事業団において 1989 年から 2004 年ま でに実施された、間接検定の調査牛 4,617 頭のデー夕 を用いて推定した遺伝率は、DG で 0.51 、BMS で 0.72 、 ロース芯面積で 0.64 、皮下脂肪厚で 0.45 、枝肉重量で 0.57 、バラの厚さで 0.48 、歩留基準值で 0.65 であり (未公表)、広域後代検定での推定値の方が、枝肉重量 とバラの厚さでやや大きく、皮下脂肪厚と歩留基準值 でやや小さく推定されたが、DG、BMS およびロース 芯面積ではほぼ同程度であった。

\section{(3) フィールド検定}

a）血縁情報

評価に用いた血縁情報については、ステーション検 定と同じ方法で構築した。

b）評価モデルの選定

評価に用いたデー夕数の評価回次に伴う推移を表 9 に示した。フィールド検定の評価では、県有種雄牛と 基準種雄牛のデー夕を用いている。平成 14 年度当初 は200頭程度のデータで評価を行う必要があった。

平成 14 年度時点での各県での出荷市場別頭数を 表 10 に示した。東日本と西日本で完全に出荷してい

表 9. 種雄牛頭数および調査牛頭数の推移(フィールド)

\begin{tabular}{lrrrrr}
\hline \multirow{2}{*}{ 評価時期 } & \multicolumn{2}{c}{ 種雄牛数 } & & \multicolumn{2}{c}{ 調査牛数 } \\
\cline { 2 - 3 } \cline { 6 - 6 } & 県有 & 総数 & & 県有 & 総数 \\
\hline $\mathrm{H} 14$ & 12 & 14 & 159 & 207 \\
$\mathrm{H} 15-1$ & 40 & 42 & 588 & 752 \\
$\mathrm{H} 15-2$ & 57 & 60 & 852 & 1,049 \\
\hline
\end{tabular}

表 10. 各県での出荷市場別頭数 (フィールド)

\begin{tabular}{crcccc}
\hline 市場 & 岩手 & 宮城 & 鳥取 & 広島 & 小計 \\
\hline 岩手 & 64 & & & & 64 \\
仙台 & 1 & 41 & & & 42 \\
山形 & 3 & & & & 3 \\
東京 & 10 & 1 & & & 11 \\
大阪 & & & 5 & 1 & 6 \\
神戸 & & 4 & 2 & 6 \\
鳥取 & & 9 & & 9 \\
広島 1 & & & & 25 & 25 \\
広島 2 & & & & 41 & 41 \\
-- 小計 & 78 & 42 & 18 & 69 & 207 \\
\hline
\end{tabular}


る市場が分かれており、また、各県で出荷先がほぼ自 県の市場に偏っている傾向が見られ、検定県と市場が 強く交絡していることが窥えた。

平成 14 年度時点での各県でのと畜月およびと畜季 節別頭数を表 11 に示した。平成 14 年度時点では、 1 〜3月にと畜されたデー夕は無く、また、4〜 5 月で のと畜データが少なかったため、開始月をより大きな 括りの季節としてグルーピングした。この際、季節の 概念は、ステーション検定とは異なり、4月からの 3 カ月区切りにした。現在の評価 (平成 15 年第 2 期評価)

表 11. 各県でのと畜月およびと畜季節別頭数 (フィールド)

\begin{tabular}{cccccc}
\hline と畜月 & 岩手 & 宮城 & 鳥取 & 広島 & 小計 \\
\hline 4 月 & & & & 1 & 1 \\
5 月 & 1 & & & 4 & 5 \\
6 月 & & 1 & & 8 & 9 \\
7 月 & & 3 & & 20 & 23 \\
8 月 & 2 & 18 & 1 & 15 & 36 \\
9 月 & 6 & & 1 & 7 & 14 \\
10 月 & 25 & 14 & 3 & 6 & 48 \\
11 月 & 27 & 6 & 6 & 6 & 45 \\
12 月 & 17 & & 7 & 2 & 26 \\
\hline \hline と畜季節 & 岩手 & 宮城 & 鳥取 & 広島 & 小計 \\
\hline $4 \sim 6$ 月 & 1 & 1 & & 13 & 15 \\
7 月 & 8 & 21 & 2 & 42 & 73 \\
$10 \sim 12$ 月 & 69 & 20 & 16 & 14 & 119 \\
\hline 小計 & 78 & 42 & 18 & 69 & 207 \\
\hline
\end{tabular}

では、ステーション検定と同じ区切りにしている。

検定場当たりの調查牛頭数を図 5 に示した。検定場 当りの調查牛頭数が 5 頭以下の検定場がほとんどであ ったことから、検定場を母数効果として取り上げるた めに、基本的に 10 頭 (一部 9 頭も含む) 未満の検定場 は県単位でグルーピングした。

以上のように、デー夕の分布を勘案しながら、評価 に用いるモデルの選定を行った。モデルに取り入れる 母数効果の候補は、性、市場、と畜月、と畜季節揖よ び検定場とし、デー夕数が少ないことから、各母数効 果は独立に扱うこととした。評価モデルの選定には、 ステーション検定と同様に、個体の育種価間の差の PEV 算出し、モデルを選定する際の指標とした。平 成 14 年度当初のデー夕 (種雄牛 14 頭)で行った分析結 果を表 12 に示した。

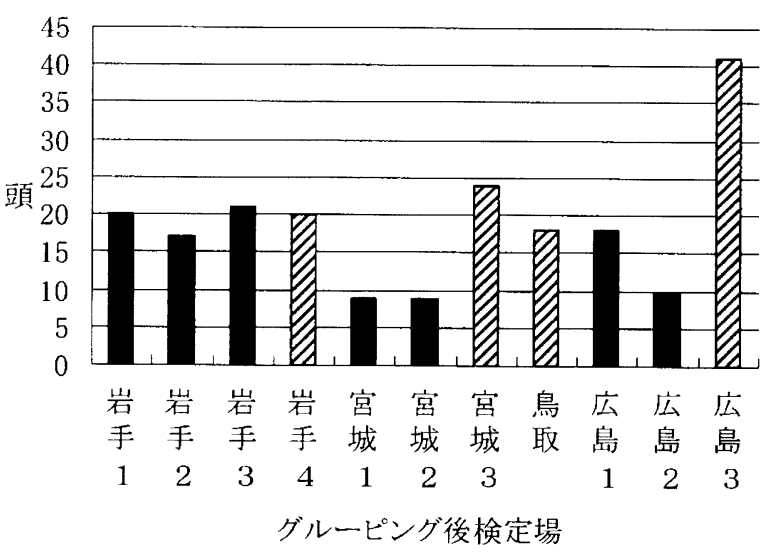

図 5. 検定場別デー夕数 (グルーピング後)

表 12. 各モデルでの個体および差のPEV (フィールド)

\begin{tabular}{|c|c|c|c|c|c|}
\hline \multirow{2}{*}{ モデル No. } & \multirow{2}{*}{ 効果 } & \multicolumn{2}{|c|}{ 個体の PEV } & \multicolumn{2}{|l|}{ 差の PEV } \\
\hline & & 平均 & 標準偏差 & 平均 & 標準偏差 \\
\hline 1 & A, F1, F2, F3-1, F4, RG1 & - & - & - & - \\
\hline 2 & $\mathrm{~A}, \mathrm{~F} 1, \mathrm{~F} 2, \mathrm{~F} 3-2, \mathrm{~F} 4, \mathrm{RG} 1$ & - & - & - & - \\
\hline 3 & $\mathrm{~A}, \mathrm{~F} 1, \mathrm{~F} 2, \quad \mathrm{~F} 4, \mathrm{RG} 1$ & - & - & - & - \\
\hline 4 & F3-1, F4, RG1 & 1.613 & 0.422 & 2.885 & 0.728 \\
\hline 5 & F3-2, F4, RG1 & 1.560 & 0.431 & 2.773 & 0.741 \\
\hline \multicolumn{6}{|l|}{ 参考 } \\
\hline 効果番号 & 効果名 & 水準数 & 効果番号 & 効果名 & 水準数 \\
\hline $\mathrm{F} 1$ & 性 & 2 & $\mathrm{~F} 4$ & 検定場 (グルーピング後) & 11 \\
\hline $\mathrm{F} 2$ & 市場 & 9 & RG1 & と畜日齢の一次回帰 & 1 \\
\hline F3-1 & と畜月 & 9 & A & 個体 & 1,439 \\
\hline F3-2 & と畜季節 & 3 & & & \\
\hline
\end{tabular}


市場を入れたモデルでは、方程式の行列が特異行列 となった。このことから、市場と検定場とが交絡し、 モデルに無理が生じていると考えられたため、市場は モデルに入れないこととした。また、と畜季節を効果 に取り入れたモデル（5）の方が、と畜月を取り入れた モデル (4) よりも差の PEVが小さく、デー夕の連結性 が高いこと、また、デー夕の分布も勘案し、モデル (5) で評価を行うこととした。

現在の評価に用いているモデル式の詳細を以下に示 した。現在は上記の効果と異なり、と畜時月齢の一次 および二次回帰を取り入れている。

$$
\begin{aligned}
y_{i j k l}= & S X_{i}+S S_{j}+G P_{k}+u_{i j k l} \\
& +a l\left(t_{i j k l}-T\right)+a 2\left(t_{i j k l}-T\right)^{2}+e_{i j k l}
\end{aligned}
$$

ここで $y_{i j k l}:$ 形質の観測值

$S X_{i}$ : 性 (母数効果)

$S S_{j}$ ：と畜季節 (母数効果)

$G P_{k}$ : グルーピング後検定場（母数効果）

$u_{i j k l}$ : 個体の育種価 (変量効果)

$t_{i j k l}:$ と畜時月齢

$T$ ：と畜時月齢の算術平均

$a 1$ ：と畜時月齢に対する一次回帰

$a 2$ ：と畜時月齢に対する二次回帰 $e_{i j k l}:$ 残差

ただし、と畜時月齢の一次および二次回帰は日齢枝肉 重量以外の形質に適用

c）平成 15 年度第 2 期評価現在の状況

平成 15 年度第 2 期評価に扔ける観測值の基本統計 量を表 13 に、評価に用いた各効果の水準数を表 14 に、 推定された遺伝的パラメータを表 15 に示した。なお、 遺伝的パラメータの推定および各個体の育種価の算出 については、ステーション検定での推定と同じプログ ラムを用いた。

向井 (1994) が 1988 年から 1994 年 2 月までに全国 24 道府県 (28 地域) で収集された枝肉格付結果約 70,000 頭のデー夕を用いて各地域単位で推定した遺伝率の重 み付け平均は、枝肉重量で 0.44 、脂肪交雑評点で 0.46 、

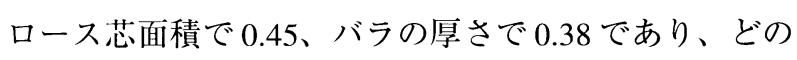
形質においても広域後代検定での推定值の方が高く推 定された。また、広域後代検定におけるステーション 検定での遺伝率 (枝肉重量で 0.79、BMS で 0.75、ロー ス芯面積で 0.64 、バラの厚さで 0.64 ：前出）よりも、 フィールド検定での推定值の方が、枝肉重量とバラの 厚さを除いて高く推定された。このことは、ステーシ ヨン検定では遺伝率が高く推定される可能性があると いう報告 (楊ら 1985 ；向井 1994）と異なっており、広

表 13. 観測值の平均 標準偏差、最大值および最小值 (フィールド)

\begin{tabular}{lcrrr}
\hline 形質名 & 頭数 & 平均 \pm 標準偏差 & 最大值 & 最小値 \\
\hline 枝肉重量 $(\mathrm{kg})$ & 1,049 & $419.25 \pm 56.41$ & 616.0 & 262.0 \\
BMS (No.) & & $5.00 \pm 1.95$ & 11 & 2 \\
ロース芯面積 $\left(\mathrm{cm}^{2}\right)$ & & $52.18 \pm 7.24$ & 85.0 & 28.0 \\
日齢枝肉重量 $(\mathrm{kg} / \mathrm{day})$ & $0.49 \pm 0.07$ & 0.81 & 0.30 \\
バラの厚さ $(\mathrm{cm})$ & $7.35 \pm 0.92$ & 11.0 & 4.3 \\
\hline
\end{tabular}

表 14. 評価に用いた効果の水準数 (フィールド)

\begin{tabular}{lc}
\hline \multicolumn{1}{c}{ 効果 } & 水準数 \\
\hline 性 & 2 \\
と畜季節 & 4 \\
グルーピング後検定場 & 39 \\
と畜時月齢の一次回帰 & 1 \\
と畜時月齢の二次回帰 & 1 \\
個体 (うち調榃牛数) & $6,963(1,049)$ \\
\hline
\end{tabular}

表 15. 遺伝分散計算結果 (フィールド)

\begin{tabular}{lcrc}
\hline 形質名 & 遺伝率 & $\begin{array}{c}\text { 遺伝分散 } \\
\left(\sigma \mathrm{a}^{2}\right)\end{array}$ & $\begin{array}{c}\text { 表型分散 } \\
\left(\sigma \mathrm{a}^{2}+\sigma \mathrm{e}^{2}\right)\end{array}$ \\
\hline 枝肉重量 $(\mathrm{kg})$ & 0.68 & $1,528.86$ & $2,247.67$ \\
BMS (No.) & 0.84 & 3.39 & 4.03 \\
ロース芯面積 $\left(\mathrm{cm}^{2}\right)$ & 0.67 & 34.58 & 51.24 \\
日齢枝肉重量 $(\mathrm{kg} / \mathrm{day})$ & 0.82 & 0.0030 & 0.0037 \\
バラの厚さ $(\mathrm{cm})$ & 0.64 & 0.51 & 0.80 \\
\hline
\end{tabular}


域後代検定におけるフィールド検定のデータが、検定 種雄牛と基準種雄牛のデー夕に限られて抢り、一般的 にフィールドから得られるデー夕と質が異なることが 原因であると思われた。

\section{（4）能力評価上の課題と検討方向}

\section{(1) 検定の一本化}

冒頭部分でも述べたが、種雄牛造成を行っている各 道県の検定方法が、間接検定 (ステーション) から現場 後代検定 (フィールド)へ移行しており、間接検定を実 施している県が減少している。このため、広域後代検 定の評価においても、ステーション評価に追加される デー夕数が減少してきている。また、現在の評価では、 検定の性質上、ステーション検定とフィールド検定か ら得られた成績を別々に評価しており、事業への参加 形態が異なる県間での種雄牛の比較ができない状況に ある。種雄牛の能力を一つの土俵で比較することが望 まれていることから、現在、事業実施道県に扔ける検 定抒よび評価のフィールドへの一本化を進めていると ころである。

\section{(2) 評価の精度}

各回次における評価の時点で可能な限り最良の評価 が実施できるように、基準種雄牛の産子の配置、デー 夕の収集状況や分布状況を勘案しながら評価モデルに ついての検討を行い、評価值を推定しているが、今後 より信頼性のおける評価值を推定するためには、デー 夕数の確保や、地域間の連結性の向上が必要である。

例えば、現在の事業の仕組みでは、利用できるデー 夕が広域後代検定で得られた調查牛のものだけであ り、ほとんどの場合、検定以外の後代記録が追加され ることによる信頼度の向上はない。種雄牛の選抜・利 用を考えた場合、一定基準を満たした検定成績から可 能な限り早期に評価値を提供する必要があるが、評価 值の正確性をより高いものにするために、フィールド 検定においては、検定後もフィールドから一般に肥育 されたデータを収集・追加して評価することも一つの 方法として考えられる。ただし、一般のフィールドか ら収集された肥育データと、あらかじめ計画を立てて 収集された検定データとの違いに配慮し、デー夕の収 集や採用の方法を検討する必要がある。

また、各検定実施道県間の連結性を高めるために、 基準種雄牛を配置しているが、各道県の全ての検定場 に配置されているわけではない。各道県の検定成績の より正確な比較を可能にするためには、各検定場の協
力と計画的な基準種雄牛の配置が必要である。

\section{4. おわりに}

広域後代検定は全国ベースでの肉用牛の能力向上を 四るために、都道府県の枠を超えた優良な育種資源の 確保と有効利用および高能力種雄牛の造成・利用の促 進を目的として実施されている。今後も、遺伝的多様 性の確保に配慮しつつ、育種資源の有効な利用と種雄 牛造成のあり方等について、育種県、関係団体、国が 協力しあい、慎重かつ効率的に発展させていく必要が あると考えられる。

\section{謝 辞}

この分析は、家畜改良增殖対策事業の中の肉用牛 改良増殖推進に倸る広域後代検定の中で行ったもの です。

本分析を遂行するにあたり、基礎分析にご協力を頂 いた(独) 農業・生物系特定産業技術研究機構畜産草地 研究所の古川力氏、分析手法についてご指導を頂いた 神戸大学農学部の向井文雄教授、検定・分析に関して 助言を頂いた委員各位に感謝の意を表します。また、 分析プログラムを利用させて頂いたジョージア大学の Misztal 氏に感謝いたします。

\section{参考文献}

Groeneveld E. 1998. VCE User's guide. Version 4.2. Institute of Animal Husbandry and Animal Sciences. Mariensee. Germany.

Kennedy BW, Trus D. 1993. Considerations on genetic connectedness between management units under an animal model. Journal of Animal Science, 71: $2341-2352$.

Meuwissen THE, Luo Z. 1992. Computing inbreeding coefficients in large populations. Genetics Selection Evolution, 24: 305-313.

Misztal I, Gianola D. 1987. Indirect solution of mixed model equations. Journal of Dairy Science, 70 (3): $716-723$.

Misztal I, Lawlor TJ, Short TH, VanRaden PM. 1992. Multiple-trait estimation of variance components of yield and type traits using an animal model. Journal of Dairy Science, 75 (2): 544-551.

Misztal I, Perez-Enciso M. 1993. Sparse matrix inversion for restricted maximum likelihood estimation of variance components by expectation-maximization. 
Journal of Dairy Science, 76 (5): 1479-1483.

向井文雄. 1994. 黒毛和種の産肉形質の選抜法ならび に遺伝的評価に関する研究. 日本畜産学会報, 65 (9): 890-905.

農林水産省大臣官房統計部. 2004. 畜産統計. 平成 16 年 2 月. 180-195. 財団法人農林統計協会. 東京.

Perez-Enciso M, Misztal I, Elzo MA. 1994. FSPAK: An interface for public domain sparse matrix subroutines. Proc. 5th World Congress Genet. Appl. Livest. Prod, 22: $87-88$.

Quaas RL. 1976. Computing the diagonal elements and inverse of a large numerator relationship matrix. Biometrics, 32: 949-953.

佐藤正寛. 2000. 大規模血統情報から近交係数を算出 するプログラムの開発. 日本養豚学会誌, 37 (3): $122-126$.

社団法人全国和牛登録協会. 1999. 和牛種雄牛産肉能 力検定成績. 間接法 (平成 9 年度) - 現場後代検定 法 (平成 10 年度). 250-251. 社団法人全国和牛登録 協会. 京都.

社団法人全国和牛登録協会. 2000a. 和牛種雄牛産肉能 力検定成績. 間接法 (平成 10 年度) - 現場後代検 定法 (平成 11 年度). 251-252. 社団法人全国和牛登 録協会. 京都. 社団法人全国和牛登録協会．2000b。和牛登録事務必 携. 平成 12 年度版. $148-159$. 社団法人全国和牛登 録協会. 京都.

社団法人全国和牛登録協会. 2001. 和牛種雄牛産肉能 力検定成績. 間接法 (平成 11 年度) - 現場後代検 定法 (平成 12 年度). 254-256. 社団法人全国和牛登 録協会. 京都.

社団法人全国和牛登録協会. 2002. 和牛種雄牛産肉能 力検定成績. 間接法 (平成 12 年度) - 現場後代検 定法 (平成 13 年度). 229-230. 社団法人全国和牛登 録協会. 京都.

社団法人全国和牛登録協会. 2003。和牛種雄牛産肉能 力検定成績. 間接法 (平成 13 年度) - 現場後代検 定法 (平成 14 年度). 2 218-329. 社団法人全国和 牛登録協会. 京都.

Wood CM, Christian LL, Rothschild MF. 1991. Use of an animal model in situations of limited subclass numbers and high degrees of relationships. Journal of Animal Science, 69: 1420-1427.

楊 茂成・向井文雄 - 佐々木義之. 1985. 黒毛和種産 肉能力検定間接法の成績に関する遺伝率および遺 伝ならびに表型相関係数の推定. 日本畜産学会報, 56: $193-198$. 